\title{
The impact of climate change on California's ecosystem services
}

\author{
M. Rebecca Shaw • Linwood Pendleton • D. Richard Cameron • Belinda Morris • \\ Dominique Bachelet • Kirk Klausmeyer • Jason MacKenzie • David R. Conklin • \\ Gregrory N. Bratman • James Lenihan • Erik Haunreiter • Christopher Daly • \\ Patrick R. Roehrdanz
}

Received: 12 February 2010 / Accepted: 26 September 2011 / Published online: 24 November 2011

(C) The Author(s) 2011. This article is published with open access at Springerlink.com

\begin{abstract}
Ecosystem services play a crucial role in sustaining human well-being and economic viability. People benefit substantially from the delivery of ecosystem services, for which substitutes usually are costly or unavailable. Climate change will substantially alter or eliminate certain ecosystem services in the future. To better understand the consequences of climate change and to develop effective means of adapting to them, it is critical that we improve our understanding of the links between climate, ecosystem service production, and the economy. This study examines the impact of climate change on the terrestrial distribution and the subsequent production and value of two key ecosystem services in California: (1) carbon sequestration and (2) natural (i.e. nonirrigated) forage production for livestock. Under various scenarios of future climate change,
\end{abstract}

M. R. Shaw $(\bowtie) \cdot$ D. R. Cameron $\cdot$ K. Klausmeyer · J. MacKenzie $\cdot$ E. Haunreiter The Environmental Defense Fund, 123 Mission Street 28th Floor, San Francisco, CA 94105, USA e-mail: rshaw@edf.org

L. Pendleton

The Nicholas Institute, Duke University, P.O. Box 90335, Durham, NC 27708, USA

e-mail: linwood.pendleton@duke.edu

B. Morris

Environmental Defense Fund, 1107 9th Street, suite 1070, Sacramento, CA 95814, USA

D. Bachelet $\cdot$ J. Lenihan

USDA Forest Service, Oregon State University, Corvallis, USA

D. R. Conklin $\cdot$ C. Daly

Conservation Biology Institute, Corvallis, USA

D. R. Conklin

e-mail: david.conklin@lifeboatearth.org

G. N. Bratman

Stanford University, Stanford, USA

P. R. Roehrdanz

University of California at Santa Barbara, Santa Barbara, USA 
we predict that the provision and value of ecosystem services decline under most, but not all, future greenhouse gas trajectories. The predicted changes would result in decreases in the economic output for the state and global economy and illustrate some of the hidden costs of climate change. Since existing information is insufficient to conduct impact analysis across most ecosystem services, a comprehensive research program focused on estimating the impacts of climate change on ecosystem services will be important for understanding, mitigating and adapting to future losses in ecosystem service production and the economic value they provide.

\section{Introduction}

Ecosystems generate a variety of goods and services important for human well-being, collectively called ecosystem services. Ecosystem services are components of nature, directly enjoyed, consumed, or used to yield human well-being (Boyd and Banzhaf 2007). These goods and services play a crucial role in sustaining economic viability in ways that may or may not be immediately understood (MA 2005a, b). Ecosystem services are categorized into four types in an effort to clarify the broad spectrum of their value and significance: provisional services (e.g., food, timber, water and fuels), regulating services (e.g., water purification and carbon sequestration), supporting services (e.g., climate regulation), and cultural services (e.g., aesthetic values and sense of place) (MA 2005a, b). It is the provisioning services that are most familiar to the general public, but the whole suite of services contributes to human well-being and generates economic value. These ecosystem goods and services generate value when they are enjoyed directly by people (e.g., eating fish) or indirectly when they support the production and quality of other things people enjoy (e.g., instream flows support recreational fishing).

The importance of valuing ecosystem services in decisions affecting natural resources and their management is highlighted in Bingham et al. (1995). A significant body of literature exists that assesses various means of quantifying the relationship of ecosystem functions to human well-being in economic terms. Mendelsohn and Olmstead (2009) provide a critical synthesis of ecosystem service valuation studies and Costanza, et al. (1997) offer an early attempt to provide an aggregate estimate of the total value of global ecosystem services. The effect climate change will have on ecosystem function has also received significant attention (see Schmitz et al. 2003; Shaver 2000, and MA 2005a, b), but it is not yet well understood how climate change will impact ecosystem services and their associated economic value in the 21 st century.

If ecosystems change dramatically as a result of climate change, the direct value we enjoy from the ecosystem services they produce also will change, in some cases dramatically. Climate change is likely to affect the abundance, production, distribution, and quality of terrestrial ecosystems. Therefore, ecosystem services such as climate stabilization through carbon sequestration, the provision of nonirrigated forage for livestock and wildlife species, the delivery of water which supports fish for commercial and recreational sport fishing, the provision of critical habitat for biodiversity, and many other types of ecosystem services are likely to be impacted by a changing climate. For example, the ability of forests to sequester carbon and thus limit climate change could be hindered as forest extent and productivity decrease and fire frequency and/or intensity increase with rising atmospheric temperatures. The distributions of grasslands suitable for forage production to support livestock grazing could shift along with changing patterns of 
precipitation. Because ecosystem services have economic value, that value is likely to change under a changing climate.

Ecosystem services contribute to state, national and global economies, which are thus vulnerable to perturbations in these services and in their net economic value. As a case study to explore this vulnerability, we focus on two ecosystem services that depend on the type and quantity of vegetation cover in California. By focusing on these two concrete examples for which we have in-depth knowledge, we hope to demonstrate how climate change can lead to changes in the provision and value of ecosystem services and in doing so shed light on the potential magnitude of economic effects that could result from the impacts of climate change on ecosystems.

Specifically, we focus on the direct effects climate change may have on (1) ecosystem attributes that influence the timing, magnitude and geographic distribution of ecosystem service production (e.g. ecosystem extent and distribution) and (2) the subsequent impacts on the production of ecosystem services including carbon sequestration, or the ability of terrestrial ecosystems to store carbon, and forage production, or the production of native or naturalized, non-irrigated vegetation by woodlands and grasslands, for cattle. We then (3) establish the link between these climate-induced changes in ecosystem services and potential impacts to economic values by estimating changes to the future net economic value of carbon sequestration and forage production. We chose these two ecosystem services for analysis because climate change impacts to the provision of each service can be directly projected and quantified using existing models and the subsequent economic value can be directly quantified through current markets or rigorous estimates of social, net economic value. Finally, we discuss the importance of future research to consider the economic impacts of climate change, and adaptation to climate change, on other ecosystem services. By bringing together climate, biophysical and economic models in a spatial analysis, it is our intent to highlight the integrated and interdisciplinary nature of examining the impact of climate change on ecosystem services and their value. We also underscore the need for a more directed and concerted research effort for accurately projecting potential changes to the future delivery of these vital services that underpin human well-being.

\section{Methods}

This section describes the methods used to (1) generate climate change projection data for California under two emissions scenarios, (2) model the impact climate change will have on ecosystems and provision of two ecosystem services, and (3) assess the value of the projected changes on those services (carbon sequestration and forage production).

\subsection{Biophysical models}

\subsubsection{Climate data and projections}

To explore the range of impacts on California ecosystem services projected, we consider the Intergovernmental Panel for Climate Change's (IPCC) high (A2) versus low (B1) greenhouse gas emissions scenarios (IPCC 2007); and three atmospheric-oceanic general circulation models (AOGCMs): GFDL-CM2.1 (Delworth et al. 2006), NCAR-CCSM3 (Collins et al. 2006, data only shown for carbon sequestration), and NCAR-PCM1 (Washington et al. 2000). The AOGCM data were statistically downscaled to $12 \mathrm{~km}$ resolution using the bias correction and spatial disaggregation (BCSD) method (Wood et al. 
2004; Maurer and Hidalgo 2008; Hugo et al. 2008). Each AOGCM was selected based upon strong regional performance in California and were selected to bracket future projected extremes ranging from a warm, wet future (NCAR-PCM1) to a hot, dry future (GFDL-CM2.1, NCAR-CCSM3).

We used three sets of climatic data for terrestrial California in this analysis: (1) historical climate data generated from interpolating weather station data from 1895 to 2006 across the state (PRISM Group, Oregon State University); (2) constructed climate neutral future based on historical trends from 2005 to 2099; (3) projected future climate from the downscaled results of the AOGCMs from 2005 to 2099. We then summarized our results based on 43-year time periods; one historical time period (1961 to 1990) and three future time periods (2005-2034, 2035-2064, and 2070-2099).

\subsubsection{Ecosystem extent and distribution}

To project changes in vegetation distribution throughout California, we used the MC1 Dynamic Global Vegetation Model (MC1-DGVM) developed by the U.S. Forest Service (USFS) and Oregon State University at the Forestry Sciences Laboratory, Corvallis, Oregon. MC1 is a dynamic vegetation model that estimates the distribution of vegetation and associated carbon, nutrients, and water fluxes and pools. The biogeochemistry module is a modified version of the CENTURY model (Parton et al. 1994), which simulates plant productivity, organic matter decomposition, and water and nutrient cycling (Bachelet et al. 2004). The direct effect of an increase in atmospheric carbon dioxide $\left(\mathrm{CO}_{2}\right)$ is simulated using a beta factor (Friedlingstein et al. 1995) that increases maximum potential productivity (about $10 \%$ increase in net primary productivity at $550 \mathrm{ppm}$ ) and reduces proportionally the moisture constraint on productivity. The fire module (Lenihan et al. 2008b) simulates the occurrence, behavior, and effects of fire using several mechanistic fire behavior functions (Rothermel 1972; Cohen and Deeming 1985; Peterson and Ryan 1986; van Wagner 1993; Keane et al. 1997) that provide interaction between the biogeography and biogeochemistry modules (Lenihan et al. 2003). The current life form mixture is used to select factors that allocate live and dead biomass into different classes of live and dead fuels. The moisture content of the live fuel classes is estimated from soil moisture provided by the biogeochemical module. Dead fuel moisture content is estimated directly from climatic inputs (Cohen and Deeming 1985). Fire events are triggered in the model when the Build Up Index and the Fine Fuel Moisture Code (BUI and FFMC of the Canadian Forest Fire Weather Index System) meet set thresholds. Sources of ignition (e.g., lightning or anthropogenic) are assumed to always be available. The fraction of a cell burned by a fire event is estimated as a function of the prescribed mean fire return interval for each vegetation type, and of the number of years since a simulated fire event. Fire effects include the consumption and the mortality of dead and live vegetation carbon (functions of fire line intensity and tree canopy structure, Peterson and Ryan 1986), which is removed from (or transferred to) the appropriate carbon pools in the biogeochemistry module. Dead biomass consumption is simulated using functions of fuel moisture that are fuel-class specific (Anderson et al. 2005).

\subsubsection{Carbon sequestration}

The MC1 model generates the monthly estimates of carbon stored or lost in each grid cell under historical climate, neutral future climate, and future climate change scenarios. We generate results for all ecosystem carbon pools but we focus the analysis on above-ground live tree carbon to be consistent with the existing protocol within the Climate Action 
Reserve (CAR) a protocol that focuses on securing carbon offsets under a cap and trade program capitalizing on the carbon stored as live tree biomass (tree bole [trunk], roots, branches, leaves/needles) and dead standing wood. (www.climateregistry.org/tools/protocols/project-protocols/forests.html). This provides a conservative estimate of the carbon stored by terrestrial forest systems since it does not take into account below-ground carbon storage pools.

We ran $\mathrm{MC} 1$ for both historical and future climate conditions and documented changes in (1) carbon pools (stems, leaves, branches, roots) and (2) soil carbon and soil moisture; (3) wildfire occurrence and impacts to estimate carbon losses and changes in the resilience of ecosystems if/when the fire regime changes; and (4) vegetation cover that will affect species range and extent, and ecosystem service production. We then averaged the summed annual carbon pool values for each of the four 30-year time periods and subtracted the carbon pools generated for the neutral climate future dataset from the projected carbon pools for each of six model-emission combinations to describe potential change due to climate change.

We accounted for urban expansion impacts on carbon sequestration potential by including estimates of future urban growth. For the baseline urban and agricultural land cover, we used the Multi-source Land Cover data to represent the extent statewide. We held agricultural land cover constant in all time periods. The agricultural extent represents row crops and other intensive agriculture, not rangelands or timberlands. For the future extent of urban lands in 2035, 2065, and 2100, we used the methods described in Sanstead et al. (2009). We calculated urban extent for each 1/ $8^{\circ}$ grid cell using the mid-range projections for household density and set a threshold of 1 unit per hectare as the minimum density for "urban". We combined this urban extent data with the agricultural extent to generate a combined "converted land" extent. The percentage of the remaining natural cover in each cell was multiplied by the carbon and forage production values to account for the additional impact of future urbanization on these services.

\subsubsection{Forage production}

Annual natural (non-irrigated) forage production for livestock in California is determined primarily by the amount and timing of precipitation. We analyzed the projected changes in distribution of the production of forage vegetation within grassland and oak woodland habitat under future climate scenarios using monthly precipitation data from two AOGCMs for each emissions scenario, the projected vegetation production from $\mathrm{MC1}$, and the Natural Resources Conservation Service (NRCS) State Soil Geographic (STATSGO) soil data. We use the following formula to estimate monthly forage production/precipitation relationship for grid cell $\mathrm{x}$ :

$$
\text { Monthly Forage Per Precipitation }=\frac{\left(\text { Forage }_{\text {ann }}{ }^{*} \text { Productivity } \text { Pct }_{\text {monthly }}\right)}{\text { Precipitation }_{\text {monthly }}}
$$

For each emission/AOGCM combination, we used the average monthly precipitation for each grid cell to generate the estimates of production. Because the timing of precipitation greatly affects the forage production, we used the growth curve for rangeland sites available through the NRCS Ecological Site Description website (http://esis.sc.egov.usda.gov) to proportionally allocate the annual range production into growing season months. We summed the resultant monthly production across the six growing season months to generate 
the annual production for each cell (pounds/acre, $\mathrm{kg} / \mathrm{ha}$ ). To account for the effects of current and projected anthropogenic land cover on forage availability, we multiplied the annual production value for each grid by the percentage of each grid cell in agriculture or urban for each time period and subtracted those from the estimate of available rangeland forage. We define rangelands as areas in either herbaceous or hardwood woodland land cover including non-irrigated grasslands and woodlands with shrubs that produce forage for livestock and wildlife. Modeling other factors that may affect the carrying capacity of rangeland for livestock such as the nutrient content of the forage, management costs, or adjacent land ownership is beyond the scope of this study.

\subsection{Economic valuation}

\subsubsection{Carbon sequestration valuation}

We estimate the net economic effects of carbon sequestration using the social cost of carbon (SCC). The SCC measures the full global net economic impact today of emitting an incremental unit of carbon at some point of time in the future, and it includes the sum of the global cost of the damage it imposes the entire time it is in the atmosphere (Price et al. 2007; Pearce 2003). The SCC attempts to capture how much society would be willing to pay to avoid damage from climate change in the future and still be as well off as they would be in the absence of climate change.

In 2005, Richard Tol published a meta-analysis of 103 estimates from 28 public studies of the marginal net economic costs of $\mathrm{CO}_{2}$ emissions. In 2008, Tol further refined his analysis. With conservative assumptions, Tol determined the mean for peerreviewed estimates is \$23/metric ton of carbon (MTC). Watkiss and Downing (2008) provided further updates of Tol and reported that in 2002, the UK Government recommended a marginal global SCC estimate of \$185/MTC (USD 2007), with a range of $\$ 93$ to $\$ 371$ with all three estimates increasing $\$ 1.50 / \mathrm{MTC}$ per year from the year 2000. We conservatively consider a central value from Watkiss and Downing of $\$ 185 /$ MTC noting that the authors expect significant increases in this value over time.

Nordhaus (2008) used the DICE-2007 model, to estimate the optimal carbon taxes that would accurately reflect the cost of carbon emissions and showed that the trajectory of optimal carbon prices (e.g. carbon taxes or the SCC) should rise to reflect the increasing damage caused by climate change and the need for increasingly tight constraints. In the model, the optimal price rises steadily over time, at between $2 \%$ and $3 \%$ per year in real terms, to reflect the rising damages from climate change. In this trajectory, Nordhaus' carbon price rises from $\$ 34 /$ MTC to $\$ 113 /$ MTC by 2050 and $\$ 251$ per MTC in 2100 all of which reflect the SCC as predicted by the DICE model.

To account for the range of accepted SCC values, we present the social value of carbon sequestration with estimates of SCC from Tol (2008), Watkiss and Downing (2008), and Nordhaus (2008).

\subsubsection{Forage valuation}

For the purposes of this study, we examine the economic value of natural, non-irrigated forage as an input to the livestock market. In our analysis, we estimate the value of nonirrigated forage production using two methods for valuation-replacement of feed and as an intermediate good in the production of livestock. To be conservative, we do not value 
quality of life, landscape generated by grazing lands nor do we estimate the costs associated with fire and invasive species management. We also do not attempt to calculate what, if any, additional costs to society would be created by changes in greenhouse gases caused by more or fewer head of cattle.

We consider the final ecosystem service (or end product) of forage production to be livestock. We identify the following two mechanisms for valuing forage production: (1) the market in livestock and its products (see Chan et al. 2006); and (2) the price of the least cost replacement for forage as a livestock feed.

In our land cover model, each cell of rangeland generates associated forage dry matter (DM) in units of annual tons, which in turn supports livestock production. We measure animal production from forage as an Animal Unit Month (AUM). AUM values can range up to $1,000 \mathrm{lbs}(454.5 \mathrm{~kg}) \mathrm{DM}$, depending on forage quality. Recent studies support an average of $791 \mathrm{lbs}(359.5 \mathrm{~kg})$ of DM as equivalent to one AUM (Brown et al. 2004; Thorne et al. 2007), the value we use in our calculations, which represents high quality forage and likely results in a high estimate for total available forage. We also assume only $50 \%$ of the forage produced on an acre of land is available for livestock production; the rest must be used for management of land productivity, or it is lost due to trampling and contamination from animal waste. This $50 \%$ utilization is based on perennial grasslands as opposed to annual grasslands. By using this conversion rate, we may underestimate potential forage production and err on the side of conservatism. If climate change dramatically reduces production, the $50 \%$ rule may overestimate utilization.

The value of the marginal product of forage (change in market value due to change in forage), expressed in profits per AUM, provides a lower bound estimate for the economic value of forage production. Brown et al. (2004) consider costs and revenues on ranches in each county in California. They report the following as average statewide values (USD 2007).

Average per cow profitability :

Annual average DM requirements per cow :

$\$$ profit per pound of DM :

\section{\$110.00(2007 USD)}

9, 492 lbs(12 months@ 791 lbs $(359.5$ kg)/AUM $))$ $\$ 0.011553(.025495$ per $\mathrm{kg})$ in profit

To calculate the climate change impacts on the economic value of change in forage production due to climate change, we assume only $50 \%$ of forage is available for livestock (see above biophysical model description) in order to arrive at the quantity of forage available for livestock production in each month. To find the market value of climate change on forage production, we multiply the predicted change in DM (from the vegetation model) by the value of its marginal product in livestock production as measured through average state livestock prices $(\$ 0.011553$ per pound or 0.025495 per $\mathrm{kg}$ of $\mathrm{DM}$ ).

As an upper bound for the value of forage, we also consider the marginal replacement cost of forage. Following on the common practice of substituting hay for forage, we assume that the lowest grade hay available from each county in California in 2003 (USDA 2004) is an equivalent substitute for natural forage. We use the market price for low grade hay, averaged across all counties in California that provide the same hay type (USDA 2008) to calculate a maximum bound for the potential change in value of forage production resulting from climate change. Assuming that forage and hay are equally nutritious on a one-to-one basis, a simple, direct cost of forage substitution is calculated at approximately $\$ 78 / \mathrm{t}$ (\$70.91/tonne). 


\section{Results}

\subsection{Changes to ecosystem attributes, services and values}

\subsubsection{Ecosystem extent and distribution}

The MC1 DGVM projects widespread changes in the distribution of vegetation across the state by the end of the century that will impact carbon sequestration and forage production. The most pronounced change that occurs across a majority of model-emissions scenarios is a $15 \%$ to $70 \%$ increase in shrublands when compared to the neutral climate future scenario (Fig. 1). In addition, there is a consistent decline, through the end of the century, in conifer woodland and forest, as well as in herbaceous cover across all model-emisions scenarios. Under the hot, dry GFDL scenario, the model projects an increase in shrubland and hardwood forest as well as a decrease in grassland, conifer woodland and forest, under both emissions scenarios. Changes predicted under the warmer, wetter PCM1 model projections are less pronounced and vary by emissions scenario, with the exception of a 10-20\% increase in hardwood woodland and a decrease in conifer woodland and for conifer forest $(\sim 10 \%)$. Shrublands are projected to decrease $(<10 \%)$ under the B1 emissions scenario but to increase $(\sim 30 \%)$ under the A2 emissions scenario. While this study projects an increase in shrubland extent at the expense of grasslands, previous studies using the MC1 model for California have shown an increase in grasslands at the expense of woody dominated vegetation types (Lenihan et al. 2003, 2008a, b). This difference is due to two changes in the model. First, the MC1 model was calibrated to more accurately represent current actual land cover types, especially in Southern California, which is not the case with previous studies (Lenihan et al. 2003, 2006, 2008a, b). Second, we used an advanced fire model, which resulted in simulations of more frequent but lower intensity fires, which

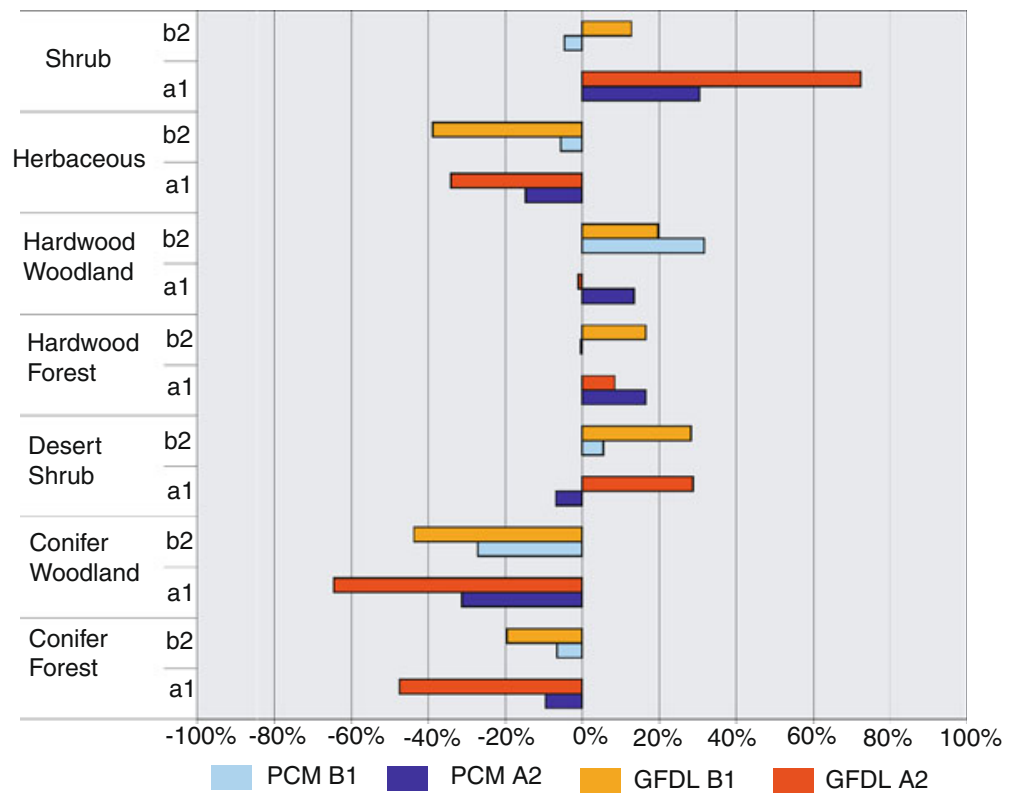

Fig. 1 Percent change in extent of major vegetation types projected by 2070-2099. The chart shows the difference between the areal extents of vegetation types in 2070-2099 as compared to the base scenario for that time period 
resulted in fire events that did not kill woody lifeforms. In addition, the increase in atmospheric $\mathrm{CO}_{2}$ throughout the 21 st century enhances shrub water use efficiency allowing them to better survive simulated drought conditions.

The spatial distribution of the projected vegetation changes by 2070 to 2099 is presented in Fig. 2. The map labeled "Historical" reflects the modeled potential natural vegetation simulated for the period spanning 1961 to 1990. The expansion of the hardwood forest up in altitude into the interior Sierra Mountain Range and up in latitude to Northern California (Modoc, Klamath, and North Coast ecoregions) is evident in all future scenarios, but it is most pronounced with the
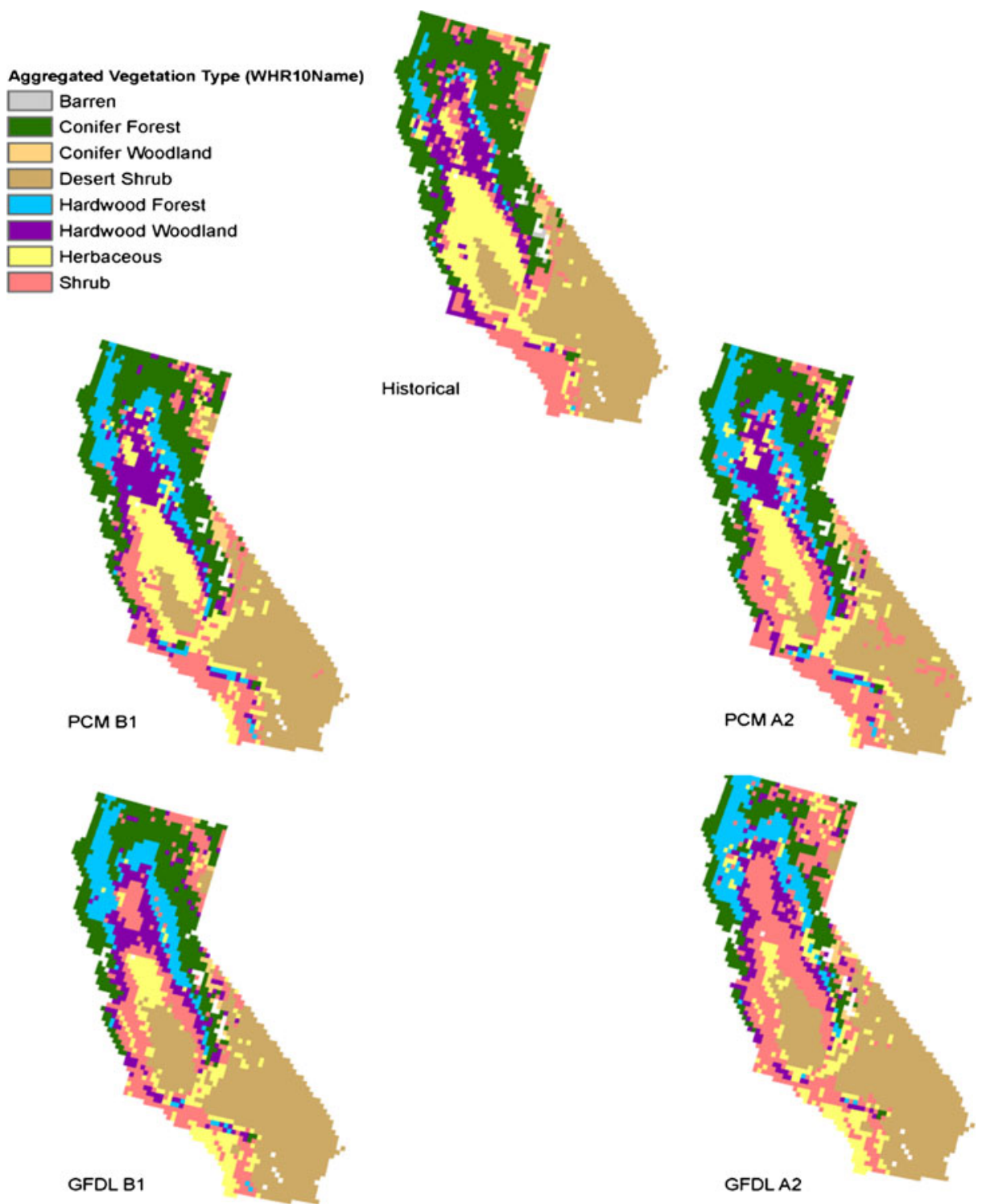

Fig. 2 Distribution of major vegetation types during historical time period (top of figure) and at the end of the 21 st century (modal values for the period 2070-2099) 
hot, dry GFDL climate under the high A2 scenario (Fig. 2). In a majority of model-emissions scenario combinations, shrublands expanded. Desert shrubland expands into the California's interior central valley in the hotter, drier GFDL model, but retreats in the warmer, wetter PCM1 climate model along the coast. Our analysis shows that land use change increases aboveground carbon loss, on average across all model-emissions scenarios, by an additional $1.5 \%$ by the end of the century.

\subsubsection{Carbon sequestration}

Projected changes in vegetation distribution will affect the carbon sequestration services provided by terrestrial ecosystems in California. The warmer, wetter climate model (PCM1) projects an increase in aboveground carbon storage relative to the neutral climate future scenario under both emissions scenarios (Fig. 3). In contrast, under the hotter, drier model (GFDL), MC1 projects much lower carbon pools than it does under neutral climate future scenario, with steep declines by the end of the century under the high A2 emissions scenario. The future climate generated by hotter, drier CCSM3 causes an even greater loss in carbon storage over the next century, with the largest loss simulated under the high A2 emissions scenario.

The spatial distribution of carbon storage in aboveground live carbon pools changes dramatically across the state by the end of the century, depending on the model-emissions scenario used. Under both the low (B1) and high (A2) emissions scenarios, there is a large increase in carbon stored by terrestrial ecosystems in the northwest of the state under the warmer, wetter climate conditions projected by PCM1. As a result, total carbon storage in live trees increases statewide, outweighing the losses in carbon in the central valley of California and along the coast. Under both

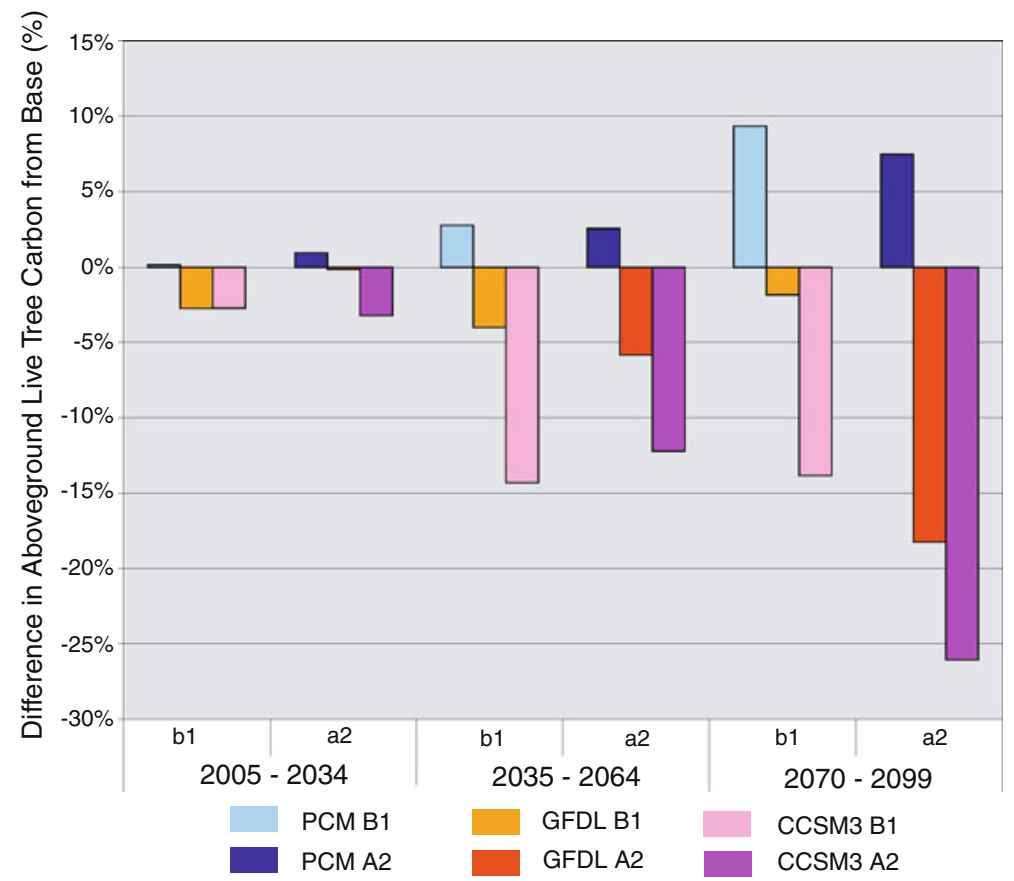

Fig. 3 Percent change from the neutral climate future in carbon storage in aboveground live tree biomass under low and high emissions scenarios for three AOGCMs (PCM1, GFDL, and CCSM3) simulated climate conditions 
Fig. 4 Percent change from the neutral climate future in forage production under low and high emissions scenarios for three AOGCMs (PCM1, GFDL, and CCSM3) simulated climate conditions

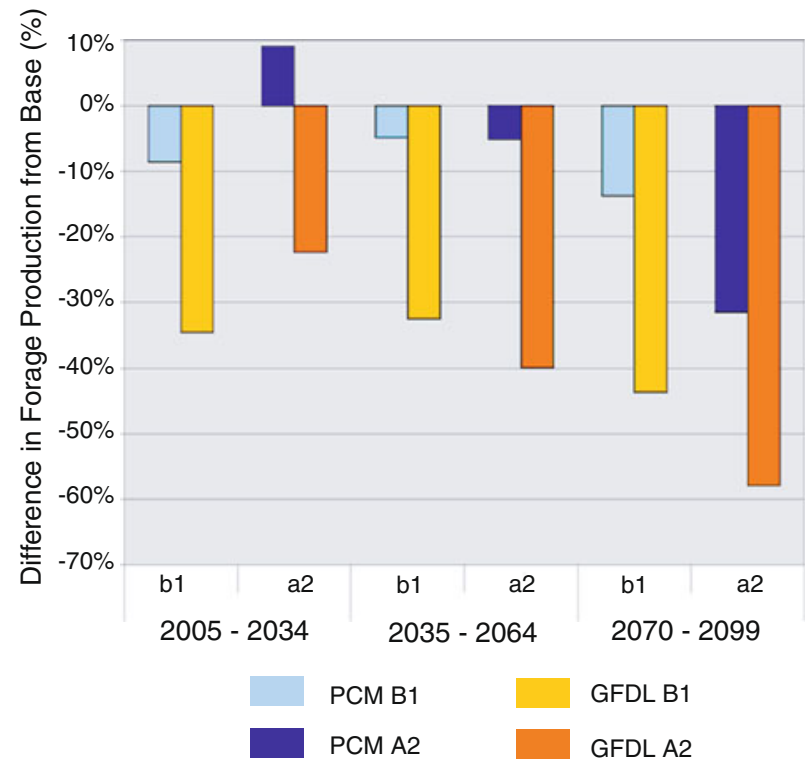

the B1 and A2 emissions scenarios, large losses in aboveground live carbon pools are projected in the eastern side of the Sierra mountain range under the future conditions simulated by the hotter, drier GFDL model, and in northern California (Klamath Mountains and Modoc Plateau) under a future simulated by the hot and dry CCSM3 model. Under the A2 emissions scenario, there are relatively few areas projected to have increased carbon storage under the hotter, drier conditions simulated by GFDL and CCSM3.

\subsubsection{Carbon sequestration value}

We estimated the net economic value due to expected climate-driven changes in the carbon stored by natural ecosystems in California. We based our estimates on the carbon storage estimates described above combined with the estimates of the social cost of carbon (SCC) released into the atmosphere (or the social benefit of carbon not released). The estimates we use for SCC are described earlier in the paper and are summarized as: a) mean values (Tol 2008), b) existing UK SCC (Watkiss and Downing 2008) and c) the globally aggregated DICE-2007 model (Nordhaus 2008) (Table 1). Driven by the warmer, wetter PCM1 climate model, the MC1 vegetation model consistently projects a higher capacity to store carbon. Consequently, the effect of climate change on natural carbon storage in California would result in a net benefit to society of \$38 million annually during the period 2005-2034 and as high as $\$ 22$ billion annually by 2070 . Driven by the hotter, drier climate model, however, the $\mathrm{MC1}$ vegetation model projects a sharp loss in carbon storage capacity in natural areas leading to social costs of $-\$ 646$ million to $-\$ 5.2$ billion annually for the period 2005-2034 (under scenario B1 using the hotter, drier CCSM3 model of climate change) to as high as $-\$ 62$ billion annually by the period $2070-2099$, under scenario high A2 using the Nordhaus' DICE-2007 model predictions.

\subsubsection{Forage production}

Forage production declines dramatically by the end of the century (2070-2099) in all future projections, ranging from a $14 \%$ decline in annual mean $(\mathrm{Tg})$ production under the warm, wet 


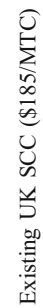
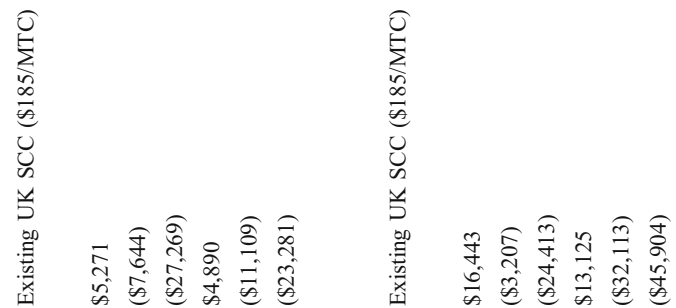

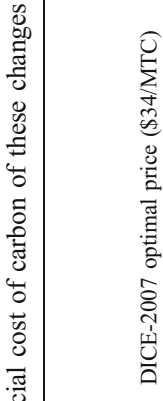

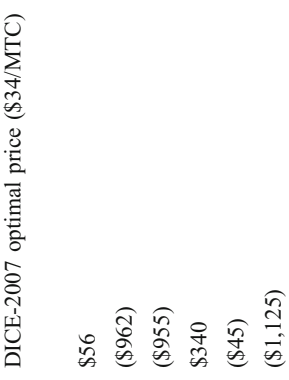

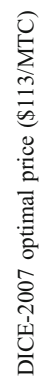

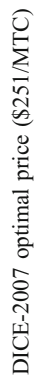

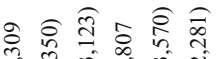

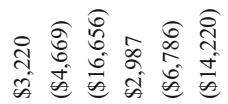

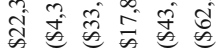

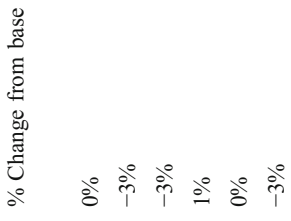

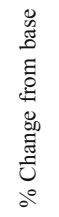

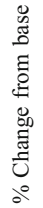

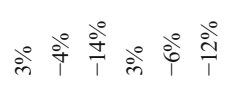

よे ڤे

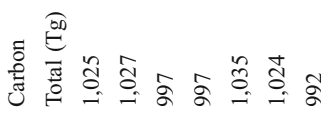

$5 \stackrel{\text { DO }}{\ominus}$

$\infty$ in $-i n \infty$ ह

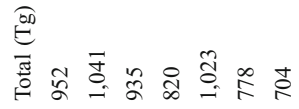

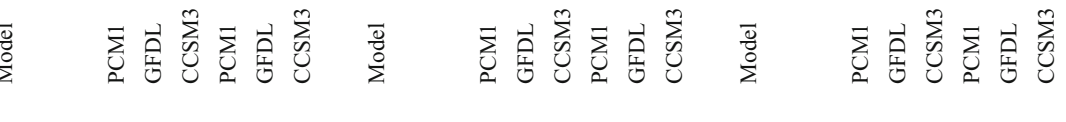
量
品

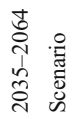

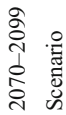
峁 
PCM1-B1 scenario to a 58\% decline under the hotter, drier, GFDL-A2 scenario. The geographic pattern of the changes in forage production projected by the end of century (2070-2099) differs dramatically among model-emissions scenarios (Fig. 4). Many of the largest losses in forage production are due to conversion of rangeland to shrublands in highly suitable climates. The spatial pattern of change in forage production driven by the warmer, wetter PCM1 model under both $\mathrm{B} 1$ and $\mathrm{A} 2$ scenarios is heterogeneous. In contrast, using the drier and warmer GFDL climate model and both B1 and A2 scenarios, the vegetation model projects extensive losses in forage production, concentrated in the inner central coastal region and along the foothills of the interior mountain range, the Sierra Nevada. The hottest and driest model-emission scenario combination, GFDL-A2, projects extensive and consistent losses in production over virtually all of the current extent of rangelands.

\subsubsection{Forage value}

Table 2 shows the potential impacts of climate change as estimated in changes of the value of natural forage for livestock. While the neutral climate future scenario for 2005-2034 projects an estimated positive increase in the value of forage (estimated at an average annual increase in profits of $\$ 15$ million using the marginal product for livestock approach or an average annual savings in hay purchases of $\$ 50$ million using the forage substitution approach), most projections show losses in forage production for all three time periods (with losses ranging between \$14 million and \$570 million). The choice of valuing forage using livestock profits or hay prices clearly makes a large difference (a factor of five) in the estimates provided here. This disparity illustrates the need for a more robust and county-specific calculation of profit

Table 2 Absolute and percent changes in forage production $(\mathrm{Tg})$ from the neutral climate future and changes in forage production value under low and high scenarios for two AOGCMs (PCM1 and GFDL) across three time periods in the future. Difference in value is millions of dollars per year averaged over the time period

\begin{tabular}{|c|c|c|c|c|c|}
\hline \multirow[t]{2}{*}{ Scenario } & \multirow[t]{2}{*}{ Model } & \multicolumn{2}{|l|}{ Forage } & \multicolumn{2}{|c|}{ Difference in value ( $\$$ million) } \\
\hline & & Total (Tg) & $\begin{array}{l}\% \text { change } \\
\text { from base }\end{array}$ & $\begin{array}{l}\text { Profits from } \\
\text { livestock }\end{array}$ & $\begin{array}{l}\text { Cost of replacement } \\
\text { for hay }\end{array}$ \\
\hline
\end{tabular}

\begin{tabular}{|c|c|c|c|c|c|}
\hline \multicolumn{6}{|c|}{$2005-2034$} \\
\hline Base & & 13 & & & \\
\hline \multirow[t]{2}{*}{ B1 } & PCM1 & 11.9 & $-8 \%$ & $(\$ 14)$ & $(\$ 47)$ \\
\hline & GFDL & 8.54 & $-34 \%$ & (\$57) & $(\$ 192)$ \\
\hline \multirow[t]{2}{*}{ A2 } & PCM1 & 14.19 & $9 \%$ & $\$ 15$ & $\$ 51$ \\
\hline & GFDL & 10.14 & $-22 \%$ & $(\$ 36)$ & $(\$ 123)$ \\
\hline \multicolumn{6}{|c|}{$2035-2064$} \\
\hline Base & & 12.24 & & & \\
\hline \multirow[t]{2}{*}{ B1 } & PCM1 & 11.65 & $-5 \%$ & $(\$ 8)$ & $(\$ 25)$ \\
\hline & GFDL & 8.28 & $-32 \%$ & $(\$ 50)$ & $(\$ 170)$ \\
\hline \multirow[t]{2}{*}{ A2 } & PCM1 & 11.63 & $-5 \%$ & $(\$ 8)$ & $(\$ 26)$ \\
\hline & GFDL & 7.39 & $-40 \%$ & $(\$ 62)$ & (\$209) \\
\hline \multicolumn{6}{|c|}{ 2070-2099 } \\
\hline Base & & 12.52 & & & \\
\hline \multirow[t]{2}{*}{$\mathrm{B} 1$} & PCM1 & 10.97 & $-14 \%$ & $(\$ 22)$ & $(\$ 74)$ \\
\hline & GFDL & 7.05 & $-44 \%$ & $(\$ 70)$ & $(\$ 235)$ \\
\hline \multirow[t]{2}{*}{$\mathrm{A} 2$} & PCM1 & 8.56 & $-32 \%$ & $(\$ 50)$ & $(\$ 170)$ \\
\hline & GFDL & 5.26 & $-58 \%$ & $(\$ 92)$ & $(\$ 312)$ \\
\hline
\end{tabular}


per AUM as well as a more thorough investigation of the true cost of a substitute for lost forage production.

\section{Discussion}

Climate change will alter the fundamental character, production, and distribution of the ecosystems that contribute to the well-being of California citizens. In this study, we show how climate change will impact terrestrial ecosystem services, especially those associated with vegetative land cover change, and their economic values (measured as net economic value). Although there have been attempts to systematically model the link between ecosystem change and ecosystem service value (e.g. de Groot et al. 2002), our scientific understanding of the link between ecosystem service production and the value to society is still in the early stages of development for most ecosystems services (Turner et al. 2003).

\subsection{Carbon sequestration by terrestrial ecosystems}

Although the exact magnitude of the economic effect of increased carbon in the atmosphere has not been defined, the literature is clear that more atmospheric carbon will lead to more climate change, which will, in turn, have economic impacts around the globe (IPCC 2007). Indeed, the effects of climate change on the ability of California ecosystems to store carbon could result in more carbon being released into the atmosphere. The impact of these changes differs substantially depending upon the climate change models and scenarios employed. Models that predict a wetter future climate indicate that California terrestrial ecosystems could increase in their carbon sequestering capabilities and could generate additional value to the world's economy of over to $\$ 300$ million annually in the near future and as much as $\$ 22$ billion annually by 2070 (Table 1). Other models of climate change, however, are far more pessimistic, predicting social costs from climate change of $-\$ 650$ million to more than $-\$ 5$ billion annually for the period 2005-2034 under the low (B1) emission scenario using the hotter, drier CCSM3 model of climate change to as high as $-\$ 62$ billion annually by the period 2070-2099 (Table 1).

\subsection{The value of natural, non-irrigated forage}

Despite some localized variation and spatial heterogeneity in the impacts of climate change, our projections of the ecosystem services associated with land cover vegetation show that climate change will lead to a reduction in the statewide provision of forage under most model-emissions scenarios by the end of the century. As a result, the economic value of forage production in California (measured as lost profits or increased costs of feeding cattle) will be substantially lower under climate change. In the near term, annual changes in profits are predicted to range from a slight increase in profits ( $\$ 15$ million) to losses of up to $\$ 36$ million (Table 2). By 2070, the average annual profits of cattle ranching could be between $\$ 22$ million and \$92 million lower due to climate change. To put these figures in context, we consider what steps ranchers may take to offset losses of natural forage. We estimate the least-cost option of replacing natural forage with hay and find that the cost of replacing lost forage with hay could be as high as $\$ 235$ million per year. As a result of the loss in forage production, most model-emissions scenarios predict that climate change will result in significant losses in the economic value of cattle and forage-reliant livestock industries in California. 


\subsection{The market value of natural carbon sequestration}

In this paper we estimate the net economic effects of carbon sequestration using the social cost of carbon. The market value of carbon could also be used to estimate the value of carbon sequestration as long as the carbon sequestered is 'additional' to an established baseline, meaning that project-based greenhouse gas emissions reductions are additional to what would have happened under a business as usual scenario (VCS 2008). The market value of carbon reflects the least-cost method for reducing carbon emissions in the atmosphere, as revealed by the market. Generally, market price is determined by the cost of meeting a cap on total carbon permitted to be released into the atmosphere through reductions in carbon emission or through the sequestration of carbon. Currently, carbon trading occurs through a number of allowancebased markets and project based transactions. The two main markets are the European Union Emissions Trading Scheme (EU ETS) and the New South Whales GHG Reduction Scheme, which are both regulated markets. Additionally, a compliance-based cap and trade program is planned to begin in 2012 under California's Global Warming Solutions Act of 2006 (Assembly Bill 32). The program allows for $8 \%$ of emissions to be achieved through offsets, and offsets achieved through forest carbon sequestration (aboveground live biomass in trees) are included in the program. The actual market value of forest carbon will depend on the development of this program. If emissions from forests were included in the cap, then the market price could be used to estimate the change in value of forest carbon resulting from climate change impacts. As forests are not included in the cap, we only estimate the change in value to landowners who may be eligible to participate in offset markets.

\subsection{Other economic impacts of climate change}

Changes in precipitation, temperature and ecosystem distribution with climate change will alter the timing and distribution of water availability in the future which will impact an array ecosystem services on which we depend including the delivery of clean water for drinking and food production, the generation of electricity through hydropower, the transportation, recreation, and the mitigation of floods. In California, all climate change projections show a shift in the proportion of precipitation falling as rain rather than snow in the mountains, a shift to higher river flows earlier in the spring and a shift in river flow from northern rivers to southern rivers. Under all emissions scenarios and all climate models, all rivers show an increase in average flow from January to April by the end of the century (2070-2099) compared to the historical period and a decrease in average flow from April to October with the greatest drops in June and July (Shaw et al. 2009). This temporal shift in flow will be compounded by spatial shifts in precipitation that increase instream flow in the southern rivers at the expense of the northern rivers.

These shifts will cause a disruption in the delivery of many ecosystem services and their values, but we have yet to fully comprehend the impact to our economy. The economic values associated with the provision of surface water differ depending on the ultimate use of water. The values, but arise from the direct use of water by residences, municipalities and industry, irrigation for farming, and hydropower. Indirectly, surface water is an intermediate input to commercial fisheries, recreational fishing, recreational boating, and snow-related recreation. These intermediate services, in turn, affect the production of end users or final services. Change in instream flow impacts commercial fisheries, recreational fishing, recreational boating, municipal and industrial use, irrigation, hydropower and flood mitigation. For example, the primary effects of climate change on recreational fishing for salmon is through its impact on stream temperature and precipitation-related changes to the quantity and timing of stream flow, especially the timing of spring runoff and average flow (Flemming and Jensen 2002; Anderson et al. 1993). Change in snowpack can affect 
related recreation (skiing/snowmobiling), flood mitigation, municipal and industrial use, and hydropower. Excessive surface water can also provide an economic disservice or economic cost by creating flooding and causing coastal and freshwater pollution that can affect beach and other recreation.

Another important attribute of ecosystem change that contributes significantly to ecosystem service production is biodiversity (Edwards and Abivardi 1998). Loss of species, especially iconic species around which tourism industries are developed, will have an impact on the economic well-being of California residents as the economy in many parts of California is dependent on tourists who come to California, in part or specifically, to see such species as otters, redwoods, sequoias, condors, and many more plants and animals (USFWS 2007). Projected species' response to climate change varies considerably between alternative emissions scenarios but we expect species migrations to track shifting climates poleward, higher in altitude, toward the coast and toward stable water sources with large contractions of suitable areas for persistence across the state (Shaw et al. 2009). Under scenarios of hotter, drier future climate, the magnitude of the simulated species' responses and loss is greater. Because of the complex interactions between plants, animals, and humans under a changed climate, we do not yet have a comprehensive understanding of the impacts of climate change on biodiversity, ecosystem function, ecosystem and species distribution, nor ecosystem resilience.

In addition, ecosystems generate value beyond those that appear in organized markets. In some cases, especially recreational services that depend on ecosystems, Californians enjoy economic benefits that exceed what they have to pay. These non-market values are important and changes in these values due to climate change can represent real losses in the economic well-being of Californians. Indirectly, some changes in non-market values can eventually reveal themselves in the hedonic value of homes near recreation sites, the cost of hotels, and other premiums that can be charged to recreationists. Much of this value, however, resides with the user. The economic well-being of homeowners, land owners, outdoor workers, and even motorists who choose to drive on scenic byways depend on ecosystem conditions. All of these non-market values could change substantially due to climate change. Future research is needed to understand how recreational behavior, home values, and other non-market economic behavior will likely change due to climate change.

\subsection{The challenges with estimating the economic effects of climate change}

The results of this study demonstrate that there remains a great deal of uncertainty in our understanding of the potential economic effects of climate change, even on services like carbon sequestration and forage for which we have relatively more data than other types of ecosystem services. We find that climate change could have positive or negative impacts on the ability of natural systems to sequester carbon and that these differences can vary spatially and temporally by several orders of magnitude depending on the levels of anthropogenic emissions. We are hampered in our ability to provide precise estimates of the value of changes in natural forage due to climate change because the quality and value of forage differs significantly across the state. Observations and models indicate that these systems are sensitive to climatic conditions, but the precise impacts of change are greatly uncertain.

The challenges in estimating the potential economic impacts of climate change include uncertainty in a) the amount of anthropogenic carbon that will be emitted into the atmosphere, b) the effects of atmospheric carbon on atmospheric temperature and precipitation, c) our understanding of how ecosystems and ecosystem outputs will change due to these changes, and d) how human beings and economic activity may change as a result of ecosystem change.

Part of the uncertainty associated with our ability to predict the future impacts of climate change is linked to our inability to predict long-term weather patterns and teleconnections 
which are complex systems and we are only beginning to understand the complexity needed for modelling. More fundamental, however, is the fact that we have yet to collect long-term, spatially explicit data on enough types of ecosystems, ecosystem services, and how people use and benefit from these ecosystem services. We know these ecosystems are sensitive to climate and weather, we know people value the goods and services produced by these ecosystems, but our knowledge of just how climate affects ecosystems and how ecosystems affect people is still rudimentary. Without good, coordinated data on ecosystems, ecosystem services, and human uses and benefits of ecosystem services we are unable to accurately predict the future effects of climate change on people and economies, nor are we able to predict how these effects differ across states, regions, or the world.

If we are to plan to adapt to future impacts of climate change, it is essential that we begin now to collect rigorous and consistent data on ecosystems, ecosystem services, and human uses and values for ecosystem services. These data should meet the same criteria already in place for the data we collect to monitor and model climate and important economic sectors: the data must be rigorous, collected systematically across the nation, and collected at relevant spatial and temporal intervals that are sufficient to allow scientists to understand the effects of change in these systems. Most importantly the data collected across atmospheric, biophysical, and human systems should integrate well to facilitate statistical analyses, modelling and decision making under uncertainty.

\section{Conclusion}

Our research reveals that climate change will affect the distribution and production of terrestrial ecosystems and the services they provide. Yet, our understanding of how ecosystem services contribute to economic well-being and productivity is still rudimentary. Beyond a general knowledge of the overall importance of ecosystem services, we have only a few concrete examples of the value of these ecosystem services. Even more rudimentary is our understanding of how these ecosystem services will change due to climate change, how these changes will affect people and the economy, and how the economy will respond to these changes. The problem isn't just uncertainty about the future, but our general lack of understanding of how to deal with risk and make decision under this uncertainty.

We highlight two ecosystem services for which we have some knowledge. Our findings show that even small changes in terrestrial ecosystem productivity can cause large changes in the value of the ecosystem service, but the uncertainty of any given outcome is huge. In the case of the economic value of carbon sequestration - a service that helps mitigate climate changethis value is large and shared globally. In the case of natural forage, its global impact is smaller, but its proportional impact looms large on the sectors affected. It is important to remember that these examples were chosen not because of the size of their expected change, but largely because of the availability of data, the feasibility of modeling change in the ecosystem and the subsequent change in the ecosystem service production, and availability of methods to value the change in ecosystem service. There are likely to be many other ecosystem services for which the effects of climate change will be larger and proportionately more important. For instance, consider the potential effect of climate change on: the ability of forests and natural vegetation to moderate urban and suburban temperatures; the ability of the ocean and coastal habitats to sequester carbon, cool coastal areas (important to people and to agriculture), and provide seafood and recreation; the ability of montane and riparian forests to recharge groundwater and protect against flooding; the contribution of natural pollinators to agriculture, horticulture, and even home gardens; the list goes on. 
To better understand, avoid, and adapt to the impacts of climate change on our economy, it is critical that we develop a better quantitative understanding of the links between climate change, ecosystems, and economic activity. While we have begun to develop a literature on the economic value of many of these ecosystem services we are largely ignorant of the value of ecosystem services to the economy and even less knowledgeable about the ways in which climate change will affect these services and how we can best adapt to these changes. Our approach has not been systematic and has not been designed to specifically address those ecosystem services that are most likely to change due to changes in climate. We recommend a research agenda that employs a strategic approach to prioritizing, understanding and modeling the impacts of climate change (and other environmental change) on ecosystem services. We also urge the development of new approaches and guidance for decision-makers and managers to deal with the uncertainty of model outcomes and the risks associated the array of decisions before them in the context of those outcomes. Until we close this gap in our understanding, we will be unable to fully comprehend or begin to mitigate and adapt to the effects of climate change on California's economy and the well-being of California residents.

Open Access This article is distributed under the terms of the Creative Commons Attribution Noncommercial License which permits any noncommercial use, distribution, and reproduction in any medium, provided the original author(s) and source are credited.

\section{References}

Anderson D, Shangle S, Scott M, Neitzel D, Chatters J (1993) "Valuing effects of climate change and fishery enhancement on Chinook Salmon.” Contemporary Policy Issues. Vol. XI, October 1993

Anderson GK, Ottmar RD, Prichard SJ (2005) CONSUME 3.0 user's guide. Pacific Wildland Fire Sciences Laboratory. USDA Foreset Service Pacific Northwest Research Station, Seattle, p 183

Bachelet D, Neilson RP, Lenihan JM, Drapek RJ (2004) Regional differences in the carbon source-sink potential of natural vegetation in the U.S. Ecol Manag 33(Supp\#1):S23-S43. doi:10.1007/s00267-003-9115-4

Bingham G, Richard B, Brody M, Bromely D, Clark E, Cooper W, Costanza R, Hale T, Hayden G, Kellert S, Norgaard R, Norton B, Payne J, Russell C, Suter G (1995) Issues in ecosystem valuation: improving information for decision making. Ecol Econ 14:73-90

Boyd J, Banzhaf S (2007) What are ecosystem services? The need for standardized environmental accounting units. Ecol Econ 63:616-626

Brown S, Dushku A, Pearson T, Shoch D, Winsten J, Sweet S (2004) "Carbon supply from changes in management of forest, range, and agricultural lands of California." Winrock International for California Energy Commission 144

Chan KMA, Shaw MR, Cameron DR, Underwood EC, Daily GC (2006) Conservation planning for ecosystem services. PLoS Biol 4:e379. doi:10.1371/journal.pbio.0040379

Cohen JD, Deeming JE (1985) The National Fire Danger Rating System: basic equations. USDA Forest Service Pacific Southwest Forest and Range Experimental StationGeneral Technical Report PSW-82. $16 \mathrm{pp}$

Collins WD, Bitz CM, Blackmon ML, Bonan GB, Bretherton CS, Carton JA, Chang P, Doney SC, Hack JJ, Henderson TB, Kiehl JT, Large WG, McKenna DS, Santer BD, Smith RD (2006) The Community Climate System Model Version 3 (CCSM3). J Clim 19:2122-2143

Costanza R, d'Arge R, de Groot R, Farber S, Grasso M, Hannon B, Limburg K, Naeem S, O’Niell RV, Paruelo J, Raskin RG, Sutton P, van den Belt M (1997) The value of the world's ecosystem services and natural capital. Nature 387:253-260

de Groot R, Wilson MA, Boumans RMJ (2002) A typology for the classification, description and valuation of ecosystem functions, goods and services. Ecol Econ 41:393-408

Delworth TL, Rosati A, Stouffer RJ, Dixon KW, Dunne J, Findell K, Ginoux P, Gnanadesikan A, Gordon CT, Griffies SM, Gudgel R, Harrison MJ, Held IM, Hemler RS, Horowitz LW, Klein SA, Knutson TR, Lin S-J, Milly PCD, Ramaswamy V, Schwarzkopf MD, Sirutis JJ, Stern WF, Spelman MJ, Winton M, 
Wittenberg AT, Wyman B (2006) GFDL's CM2 global coupled climate models. Part I: formulation and simulation characteristics. J Clim 19:643-674

Edwards PJ, Abivardi C (1998) Valuing biodiversity: where ecology and economy blend. Biol Conserv $83: 239-246$

Flemming IA, Jensen AJ (2002) Fisheries: effects of climate change on the life cycles of Salmon. Causes and Consequences of Global Environmental Change, 3:309-312. Edited by Ian Douglas in Encyclopedia of Global Environmental Change. John Wiley \& Sons, Ltd, Chichester, UK

Friedlingstein P, Fung I, Holland E, John J, Brasseur G, Erickson D, Schimel D (1995) On the contribution of $\mathrm{CO} 2$ fertilization to the missing biospheric sink. Glob Biogeochem Cycles 9:541-556

Hugo GH, Dettinger MD, Cayan DR (2008) Downscaling with constructed analogues: daily precipitation and temperature fields over the United States. California Energy Commission Report. CEC-500-2007123. January

IPCC (Intergovernmental Panel on Climate Change) (2007) Impacts, adaptation and vulnerability. Contribution of Working Group II to the Fourth Assessment Report of the Intergovernmental Panel on Climate Change. Cambridge University Press, Cambridge

Keane RE, Long D, Basford D, Levesque BA (1997) Simulating vegetation dynamics across multiple scales to assess alternative management strategies. In: Conference Proceedings - GIS 97, 11th Annual Symposium on Geographic Information Systems-Integrating Spatial Information Technologies for Tomorrow. GIS World, Inc. Vancouver, British Columbia, Canada. 310-315

Lenihan JM, Drapek RJ, Bachelet D, Neilson RP (2003) Climate changes effects on vegetation distribution, carbon, and fire in California. Ecol Appl 13:1667-1681

Lenihan JM, Bachelet D, Drapek RJ, Neilson RP (2008a) The response of vegetation distribution, ecosystem productivity, and fire in California to future climate scenarios simulated by the MC1 dynamic vegetation model. Clim Chang 87(Supp):S215-S230

Lenihan JM, Bachelet D, Neilson RP, Drapek RJ (2008b) Simulated response of conterminous United States ecosystems to climate change at different levels of fire suppression, $\mathrm{CO}_{2}$ emissions rate, and growth response to $\mathrm{CO}_{2}$. Glob Planet Chang 64:16-25

MA (Millennium Ecosystem Assessment) (2005a) Ecosystems and human well-being. Synthesis. Island, Washington

MA (Millennium Ecosystem Assessment) (2005b) Ecosystems and human well-being. Biodiversity synthesis. Island, Washington

Maurer EP, Hidalgo HG (2008) Utility of daily vs. monthly large-scale climate data: an intercomparison of two statistical downscaling methods. Hydrology Earth Syst Sci 12:551-563

Mendelsohn R, Olmstead S (2009) The economic valuation of environmental amenities and disamenities: methods and applications. Annu Rev Environ Resour 34:325-347

Nordhaus W (2008) A question of balance: weighing the options on global warming policies. Yale University Press, New Haven

Parton W, Schimel D, Ojima D, Cole C (1994) A general study model for soil organic model dynamics, sensitivity to litter chemistry, texture, and management. Soil Sci Soc America Spec Publ 39:147-167

Pearce D (2003) The social cost of carbon and its policy implications. Oxford Rev Econ Policy 19:362-384

Peterson DL, Ryan KC (1986) Modeling postfire conifer mortality for long-range planning. Environ Manag 10:797-808

Price R, Thornton S, Nelson S (2007) The social cost of carbon and the shadow price of carbon: what they are, and how to use them in economic appraisal in the UK. Department for Environment Food and Rural Affairs, UK

Rothermel RC (1972) A mathematical model for predicting fire spread in wildland fuels. Res. Pap. INT-115. Ogden, UT: U.S. Department of Agriculture, Forest Service, Intermountain Forest and Range Experiment Station

Sanstead AH, Johnson H, Goldstein N, Franco G (2009) Long-run socioeconomic and demographic scenarios for California. California Energy Commission Scenarios Report. CEC-500-2009-013-F-1

Schmitz OJ, Post E, Burns CE, Johnston KM (2003) Ecosystem responses to global climate change: moving beyond color mapping. Bioscience 53:1199-1206

Shaver GR, Canadell J, Chapin FS III, Gurevitch J, Harte J, Henry G, Ineson P, Jonasson S, Melillo J, Pitelka L, Rustad L (2002) Global warming and terrestrial ecosystems: a conceptual framework for analysis. Bioscience 50:871-883

Shaw MR, Pendleton L, Cameron R, Morris B, Bratman G, Bachelet D, Klausmeyer K, MacKenzie J, Conklin D, Lenihan J, Haunreiter E, Daly C (2009) The impact of climate change on California's ecosystem services. California Energy Commission Scenarios Report. CEC-500-2009-025-D

Thorne M, Cox LJ, Stevenson MH (2007) Calculating minimum grazing lease rates for Hawai'i. Published by the College of Tropical Agriculture and Human Resources, Pasture and Range Management 
Tol RSJ (2005) The marginal damage cost of carbon dioxide emissions: an assessment of the uncertainties. Energy Policy 33:2064-2074

Tol RSJ (2008) The social cost of carbon: trends, outliers and catastrophes. Economics: The Open-Access, Open-Assessment E-Journal, 2:2008-25

Turner RK, Paavola J, Cooper P, Farber S, Jessamy V, Georgiou S (2003) Valuing nature: lessons learned and future directions. Ecol Econ 46:493-510

United States Department of Agriculture (2008) Agricultural Marketing Service, Livestock \& Grain Market News, March, 2008. Alfalfa Hay, 2008 Year-to-date cumulative: California Market Summary

United States Fish and Wildlife Service (USFWS) (2007) 2006 National survey of fishing, hunting and wildlife-associated recreation activities: California. December, 2007

USDA (United States Department of Agriculture, National Agricultural Statistics Service) (2004) Livestock county estimates United States Department of Agriculture, Agricultural Marketing Service, Alfalfa Hay 2008 Year-to-Date cumulative, California Market Summary, March 2004

USDA (United States Department of Agriculture, National Agricultural Statistics Service) (2007) Livestock county estimates United States Department of Agriculture, Agricultural Marketing Service, Alfalfa Hay 2008 Year-to-Date cumulative, California Market Summary, March 2008

van Wagner CE (1993) Prediction of crown fire behavior in two stands of jack pine. Can J For Res 23:442449

Voluntary Carbon Standard (VCS) (2008) Voluntary carbon standard program guidelines. 18 November 2008

Washington WM, Weatherly JW, Meehl GA, Semtner AJ Jr, Bettge TW, Craig AP, Strand WG Jr, Arblaster J, Wayland VB, James R, Zhang Y (2000) Parallel climate model (PCM) control and transient simulations. Clim Dyn 16:755-774

Watkiss P, Downing TE (2008) The social cost of carbon: valuation estimates and their use in UK policy. Integr Assess J 8:85-105

Wood AW, Leung LR, Sridhar V, Lettemaier DP (2004) Hydrological implications of dynamical and statistical approaches to downscaling climate model outputs. Clim Chang 62:189-216 